Volume. 8 Nomor. 2, Mei 2021. p - 2354-8649 I e - 2579-5767

Open Access at: http://ojs.umrah.ac.id/index.php/selat

DOI: https://doi.org/10.31629/selat.v8i2.3784

\title{
PENGARUH KEDAULATAN RAKYAT TERHADAP HUBUNGAN DEWAN PERWAKILAN RAKYAT DAERAH DENGAN BADAN PEMERIKSA KEUANGAN
}

\author{
Agmalun Hasugian ${ }^{1}$, Nam Rumkel ${ }^{2}$, Irham Rosyidi ${ }^{3}$ \\ ${ }^{1}$ Mahasiswa Pasca Sarjana, Program Studi Ilmu Hukum Universitas Khairun, Ternate \\ 2,3Pasca Sarjana, Program Studi Ilmu Hukum Universitas Khairun, Ternate \\ hasugianagmalun@gmail.com, namrumkel@gmail.com, irhamrosyidi@gmail.com
}

\begin{abstract}
This research focuses on the implementation of people's sovereignty in the 1945 Constitution of the Republic of Indonesia and its implementation in the working relationship of the the Regional House of Representative (DPRD) and the Supreme Audit Board (BPK). The research problem raised is how people's sovereignty affects the relationship between DPRD and BPK and what are the relationships between the two institutions that are influenced by people's sovereignty. To reveal the research problem, normative legal research is used which prioritizes secondary data with two approaches, namely the legal approach and the conceptual approach. The results of the study reveal that the people's sovereignty in the constitution is realized through one of its principles, namely accountability. Accountability is the embodiment of people's sovereignty as a form of accountability to the people as the giver of the mandate. This principle also underlies the relationship between the DPRD and the BPK which independently has the authority to implement accountability. The relationship between the two institutions is, first, the implementation of accountability in the horizontal dimension (checks and balances), namely the examination of the BPK to the DPRD as an element of the regional government, the submission of the report on the results of the examination by the BPK to the DPRD, the form of follow-up to the audit results, and the involvement of the DPRD in planning the audit. Second, accountability in the vertical dimension in the form of accountability to the people.
\end{abstract}

Keywords: Accountability, people's sovereignty, works relations.

\begin{abstract}
Abstrak
Penelitian ini memfokuskan pada pelaksanaan kedaulatan rakyat dalam UUD NRI Tahun 1945 dan pelaksanaannya dalam hubungan kerja Dewan Perwakilan Rakyat Daerah (DPRD) dengan Badan Pemeriksa Keuangan (BPK). Problem penelitian yang diangkat adalah bagaimana kedaulatan rakyat memengaruhi hubungan antara DPRD dengan BPK dan apa sajakah hubungan antara kedua lembaga tersebut yang dipengaruhi oleh kedaulatan rakyat. Untuk mengungkap problem penelitian, digunakan penelitian hukum normatif yang mengutamakan data sekunder dengan dua pendekatan, yaitu pendekatan undang-undang dan pendekatan konseptual. Hasil penelitian menunjukkan bahwa kedaulatan rakyat dalam undang-undang dasar diwujudkan melalui salah satu prinsipnya yakni akuntabilitas. Akuntabilitas merupakan perwujudan kedaulatan rakyat sebagai bentuk pertanggungjawaban
\end{abstract}


rakyat selaku pemberi mandat. Prinsip ini juga mendasari hubungan antara DPRD dengan BPK yang secara mandiri memiliki kewenangan dalam rangka pelaksanaan akuntabilitas. Hubungan antar kedua lembaga merupakan, pertama, pelaksanaan akuntabilitas dalam dimensi horizontal (check and balances), yaitu pemeriksaan BPK kepada DPRD sebagai unsur pemerintahan daerah, penyerahan laporan hasil pemeriksaan oleh BPK kepada DPRD, Bentuk Tindak Lanjut Hasil Pemeriksaan, dan keterlibatan DPRD dalam perencanaan pemeriksaan. Kedua, akuntabilitas dalam dimensi vertikal berupa pertanggungajawaban kepada rakyat.

Kata Kunci: Akuntabilitas, hubungan kerja, kedaulatan rakyat.

\section{PENDAHULUAN}

UUD NRI tahun 1945 menganut paham kedaulatan rakyat sebagai paham yang meletakkan kekuasaan tertinggi berada di tangan rakyat. Hal ini tercermin lewat ketentuan Pasal 1 ayat (2) UUD NRI tahun 1945 yang menyatakan "Kedaulatan berada di tangan rakyat dan dilaksanakan menurut undang-undang dasar". Ketentuan tersebut juga menunjukkan bahwa UUD NRI tahun 1945 menganut kedaulatan rakyat atau demokrasi yang disalurkan dan diselenggarakan menurut prosedur konstitusional yang ditetapkan dalam hukum dan konstitusi (constitutional democracy). ${ }^{1}$ Berdasarkan ketentuan tersebut, kedaulatan rakyat didistribusikan melalui tugas dan wewenang lembaga-lembaga tinggi negara yang ditentukan kewenangannya dalam UUD NRI Tahun 1945 karena kedaulatan rakyat juga tercermin dalam struktur dan mekanisme kelembagaan negara dan pemerintahan. ${ }^{2}$ Berbeda dengan kondisi sebelum perubahan, kedaulatan berada di tangan rakyat, namun dilakukan sepenuhnya oleh MPR. ${ }^{3}$ Kedaulatan rakyat dianggap terwujud penuh dalam wadah MPR yang dapat ditafsirkan sebagai lembaga tertinggi ataupun sebagai forum tertinggi. Dari sini, fungsi-fungsi tertentu dibagikan sebagai tugas dan kewenangan lembaga-lembaga tinggi negara yang ada di bawahnya. ${ }^{4}$

Perubahan UUD 1945 tidak hanya mereposisi kedaulatan rakyat, termasuk perubahan mengenai keuangan negara. Sebelum perubahan UUD 1945, pengertian keuangan negara memiliki jangkauan yang lebih sempit yang diatur pada BAB VII yang berjudul "Hal Keuangan”. Makna yang paling erat dengan hal keuangan

\footnotetext{
1 Ofis Rikardo, "Penerapan Kedaulatan Rakyat Di Dalam Pemilihan Umum Di Indonesia Berdasarkan UndangUndang Dasar Negara Republik Indonesia Tahun 1945”, Jurnal Hukum Sasana, Vol. 6, No. 1, Juni 2020, hal. 51-71.

2 Jimly Asshiddiqie, Konstitusi dan Konstitusionalisme Indonesia, Jakarta: Sinar Grafika, 2010, hal. 137.

3 Pasal 1 ayat (2) UUD 1945 sebelum perubahan.

${ }^{4}$ Jimly Asshiddiqie, Konstitusi dan..., Loc. Cit.
} 
dimaksudkan sebagai Anggaran Pendapatan dan Belanja Negara yang ditetapkan oleh DPR bersama Pemerintah. ${ }^{5}$ Hal ini ditegaskan pula oleh Jimly Asshidiqie yang menyatakan bahwa UUD 1945 sebelum perubahan memberikan makna keuangan negara dengan hanya mengaitkannya dengan Anggaran Pendapatan dan Belanja Negara (APBN). ${ }^{6}$ Harun Al-Rasid juga mengartikan keuangan negara secara terbatas sebagai pelaksanaan Anggaran Pendapatan dan Belanja Negara. ${ }^{7}$ Maka pengertian keuangan negara dapat dipandang terbatas sebagai pengelolaan Anggaran Pendapatan dan Belanja Negara.

Setelah perubahan UUD 1945, keuangan negara memiliki pengertian hak dan kewajiban yang menyangkut keuangan atau dana milik negara yang pengelolaannya dilakukan melalui APBN, APBD, dan/atau melalui anggaran perusahaan negara dan perusahaan daerah, serta badan-badan lainnya, termasuk badan swasta, yang mengelola keuangan negara. ${ }^{8}$ Perubahan pengertian tersebut berkaitan erat pula dengan kewenangan kelembagaan negara yakni Badan Pemeriksa Keuangan (BPK). ${ }^{9}$ Sebelum perubahan UUD 1945, kewenangan BPK diatur sebagai lembaga yang hadir untuk memeriksa tanggung jawab keuangan negara. Sedangkan setelah perubahan UUD 1945 menjadi UUD NRI Tahun 1945, BPK memeriksa tanggung jawab dan pengelolaan keuangan negara.

Meluasnya cakupan keuangan negara hingga pada pengelolaan keuangan negara di daerah berdampak pada hasil pemeriksaan BPK yang tidak hanya disampaikan kepada lembaga perwakilan di tingkat pusat (DPR dan DPD). Hasil pemeriksaan BPK disampaikan pula kepada Dewan Perwakilan Rakyat Daerah (DPRD). Ketentuan tersebut berdasarkan rumusan perubahan UUD 1945 pada Pasal 23E ayat (2) yang berbunyi: "Hasil pemeriksaan keuangan negara diserahkan kepada Dewan Perwakilan Rakyat, Dewan Perwakilan Daerah, dan Dewan Perwakilan Rakyat Daerah, sesuai dengan kewenangannya." Sementara sebelum perubahan UUD 1945, hasil pemeriksaan hanya diberitahukan kepada Dewan Perwakilan Rakyat. ${ }^{10}$ Aspek keuangan negara dan tanggung jawab pengelolaannya tersebut berkaitan erat

\footnotetext{
5 Pasal 23 ayat (1) UUD 1945 sebelum perubahan.

6 Jimly Asshiddiqie, Op. Cit., hal. 819.

${ }^{7}$ Arifin P. Soeria Atmadja, Keuangan Publik dalam Perspektif Hukum, Jakarta: Rajawali Pers, 2017, hal. 4.

8 Jimly Asshiddiqie, Pokok-Pokok Hukum Tata Negara Indonesia, Jakarta: BIP, 2008, hal. 818.

${ }^{9}$ Ibid., hal. 807.

10 Pasal 23 ayat (5) UUD 1945 sebelum perubahan.
} 
242 Agmalun Hasugian, dkk, Pengaruh Kedaulatan Rakyat Terhadap Hubungan,,

dengan kewenangan kelembagaan negara yang ditentukan dalam UUD NRI Tahun 1945. ${ }^{11}$ Maka, bertambahnya kewenangan penyerahan hasil pemeriksaan keuangan kepada DPRD berkaitan erat dengan meluasnya aspek keuangan dan tanggung jawab keuangan negara. Penulis memandang hadirnya ketentuan baru yang mengamanatkan BPK untuk menyerahkan laporan hasil pemeriksaannya kepada DPRD sebagai tanda meluasnya cakupan keuangan negara, tidak hanya terbatas pada pengelolaan APBN, juga pengelolaan keuangan negara di daerah otonomi.

Pembentukan pemerintahan daerah atau pemerintahan yang berotonomi merupakan salah satu aspek pelaksanaan kedaulatan rakyat. Mekanisme yang diatur dalam UUD NRI Tahun 1945 menetapkan pelaksanaan kedaulatan rakyat dalam dua pranata, yakni: (1) pranata demokrasi secara langsung; dan (2) pranata demokrasi perwakilan. ${ }^{12}$ Maka DPRD merupakan pelembagaan pranata demokrasi perwakilan bagi masyarakat tingkat provinsi, kabupaten, dan kota. DPRD sebagai lembaga perwakilan tingkat lokal memiliki kewenangan-kewenangan dalam kaitannya dengan pengelolaan keuangan negara di daerah otonomi. Karena pada dasarnya, bersama dengan unsur pemerintah daerah, mengurus sendiri urusan pemerintahan di daerahnya sebagai amanat UUD NRI Tahun 1945. Urusan pemerintahan ini juga termasuk pengelolaan keuangan negara di daerah lewat APBD yang selanjutnya disebut sebagai keuangan daerah. Hal tersebut menyebabkan timbulnya hubungan dengan BPK sebagai pemeriksa pengelolaaan dan tangggung jawab keuangan negara yang ditentukan oleh UUD NRI Tahun 1945.

Dengan ketentuan bahwa kedaulatan berada di tangan rakyat dan dilaksanakan menurut undang-undang dasar maka hubungan yang timbul antara kedua lembaga yakni DPRD dan BPK seharusnya tidak lepas dari pengaruh pelaksanaan paham kedaualatan rakyat. Oleh karena itu permasalahan hukum yang dikaji dalam penulisan ini, yaitu bagaimana kedaulatan rakyat memengaruhi hubungan antara DPRD dengan BPK dan apa sajakah hubungan antara kedua lembaga tersebut yang dipengaruhi oleh kedaulatan rakyat. Berdasarkan kedua permasalahan tersebut, penulisan ilmiah ini bertujuan untuk menguraikan hubungan kelembagaan yang tercipta antara DPRD dengan BPK yang dipengaruhi paham kedaulatan rakyat pasca

11 Jimly Asshiddiqie, Pokok-Pokok..., ibid., hal. 807.

12 Eduardus Marius Bo, Teori Negara Hukum dan Kedaulatan Rakyat, Malang: Setara Press, 2019, hal. 55-56. 
perubahan UUD 1945. Tujuan berikutnya untuk memberikan sumbangan pemikiran khususnya dalam bidang hukum tata negara mengenai analisa terbentuknya hubungan kelembagaan antara BPK dengan DPRD.

\section{METODE PENELITIAN}

Penelitian ini merupakan penelitian hukum dengan metode hukum normatif yang mengutamakan data sekunder. Peter Mahmud Marzuki mengatakan bahwa pendekatan dalam penelitian hukum terdiri atas pendekatan undang-undang (statue approach), pendekatan kasus (case approach), pendekatan historis (historical approach), pendekatan perbandingan (comparative approach) dan pendekatan konseptual (conceptual approach). ${ }^{13}$ Dalam penelitian ini menggunakan pendekatan undang-undang dan pendekatan konseptual. Pendekatan perundang-undangan (statue approach) dilakukan dengan menelaah semua undang-undang dan regulasi yang bersangkut paut dengan isu hukum yang sedang dikaji. ${ }^{14}$ Sedangkan pendekatan konseptual (conceptual approach) ini beranjak dari pandanganpandangan dan doktrin-doktrin yang berkembang dalam ilmu hukum. Dengan mempelajari pandangan-pandangan dan doktrin-doktrin di dalam ilmu hukum, peneliti akan menemukan ide-ide yang melahirkan pengertian-pengertian hukum, konsep-konsep hukum, dan asas-asas hukum yang relevan dengan isu yang dihadapi. 15

\section{PEMBAHASAN}

\subsection{Kedaulatan Rakyat dan Pelaksanaannya dalam UUD NRI Tahun 1945}

\section{Kedaulatan Rakyat}

Kata kedaulatan berasal dari kata soverignty, souverainete, sovranus. Kata-kata asing tersebut diturunkan dari kata latin superanus yang berarti "yang tertinggi" (supreme). ${ }^{16}$ Secara etimologi, kata kedaulatan berarti superioritas belaka, namun apabila dilekatkan dalam konteks negara maka memiliki arti yang khusus.

\footnotetext{
13 Peter Mahmud Marzuki, Penelitian Hukum, Jakarta: Kencana Media Group, 2014, hal. 93.

${ }^{14}$ Ibid., hal. 133.

15 Ibid., hal. 135

16 Andryan, M. Solly Lubis, Suhaidi, Faisal Akbar Nasution, "Penguatan Fungsi Legislasi Dewan Perwakilan Daerah Dalam Sistem Ketatanegaraan Republik Indonesia (Analisis Putusan Mahkamah Konstitusi No.92/Ppu-X/2012)", USU Law Journal, Vol.3, No.2, Agustus 2015, hal. 160-167.
} 
Superioritas seperti ini mengisyaratkan adanya kekuasaan untuk membuat hukum (law-issuing power). ${ }^{17}$ H.L.A. Hart mengasumsikan bahwa dalam masyarakat manapun di mana ada hukum sesungguhnya ada satu pemegang kedaulatan. Dalam setiap masyarakat bernegara, baik dalam bentuk demokrasi maupun absolut sekalipun, terdapat hubungan sederhana antar para warga negara yang menjalankan kepatuhan dengan pemegang kedaulatan. ${ }^{18}$

Kedaulatan dalam konteks bernegara membicarakan apa dan siapa yang memegang kekuasaan tertinggi dan membuat keputusan akhir dalam kegiatan kenegaraan. Terkait hal ini dikenal adanya lima teori terkait kedaulatan, yaitu: (1) teori kedaulatan negara; (2) teori kedaulatan Tuhan; (3) teori kedaulatan raja; (4) teori kedaulatan rakyat; dan (5) teori kedaulatan hukum. ${ }^{19}$ Terkait teori kedaulatan rakyat, maka rakyat diposisikan sebagai sumber kekuasaan tertinggi dalam suatu negara, artinya rakyat berkuasa dan independen atas dirinya sendiri. ${ }^{20}$ Kedaulatan rakyat berarti pemerintahan rakyat, pemerintahan yang dilakukan oleh pemimpinpemimpin yang dipercayai oleh rakyat. ${ }^{21}$ J.J. Rousseau menyatakan bahwa konsep kedaulatan rakyat bersifat kerakyatan dan didasarkan pada kemauan umum (volunte generale) rakyat yang menjelma melalui perundang-undangan. ${ }^{22}$ Sehingga berdasarkan pendapat ini kedaulatan rakyat dapat dilembagakan dalam dan melalui hukum.

Kedaulatan rakyat tidak dapat dipisahkan dengan istilah demokrasi. Jiwa demokrasi adalah kedaulatan rakyat. ${ }^{23}$ Demokrasi dipahami sebagian sebagai peringkat atau derajat dan sebagian lagi dipahami sebagai mekanisme tertentu pemilihan saluran pengekspresian kehendak umum atau kedaulatan rakyat. Hal ini dikarenakan karakter demokrasi yang bisa berbeda-beda pada praktiknya. ${ }^{24}$ Meskipun memiliki karakter yang berbeda, setidaknya demokrasi memiliki nilainilai, ciri, atau prinsip-prinsip yang universal. Nilai-nilai demokrasi mengacu pada prinsip-prinsip dasar pemerintahan yang demokratis yang memungkinkan kita

17 C.F. Strong, Konstitusi-Konstitusi Politik Modern, Bandung: Nusamedia, 2008, hal. 9.

18 H.L.A. Hart, Konsep Hukum (The Concept of Law), Bandung: Nusamedia, 2016, hal. 79-80.

${ }^{19}$ Jimly Asshiddiqie, Pokok-Pokok Hukum..., ibid., hal. 144.

20 Khairul Fahmi, "Prinsip Kedaulatan Rakyat Dalam Penentuan Sistem Pemilihan Umum Anggota Legislatif",

Jurnal Konstitusi, Vol. 3, No. 7, Juni 2010, hal. 119-160.

21 Ibid.

22 Eduardus Marius Bo, Teori Negara Hukum..., ibid., hal. 10.

23 Ibid., hal. 22.

24 Janedri M . Gaffar, Demokrasi dan Pemilu di Indonesia, Jakarta: Konstitusi Pers, 2013, hal. 12. 
membedakan antara proses demokratis dan nondemokratis. Nilai-nilai ini mencakup namun tidak terbatas pada nilai-nilai seperti kesetaraan, keadilan yang tidak memihak, hak pilih universal, atau kebebasan ekspresi. Diantara nilai-nilai tersebut terdapat nilai-nilai inti tertentu, mewakili nilai-nilai dasar sistem politik demokrasi, yang membentuk keyakinan fundamental dan prinsip konstitusional masyarakat yang demokratis, seperti kebebasan, kesetaraan, keadilan. ${ }^{25}$ David Held memberikan pengertian dan prinsip demokrasi pada dua hal penting yaitu kebebasan dan kesetaraan. Keduanya merupakan merupakan prinsip dasar tegaknya otonomi demokrasi (democracy autonomy). ${ }^{26}$

Hendra Nurtjahyo berpendapat bahwa konsep kadaulatan rakyat memiliki tiga prinsip pokok, yaitu kebebasan, kesamaan, dan kedaulatan suara mayoritas (rakyat). ${ }^{27}$ Titik Triwulan Tutik menyatakan setidaknya ada tiga nilai ideal atau ciriciri demokrasi sebagai suatu gagasan kehidupan yaitu kemerdekaan (freedom), persamaan (equality), dan keadilan (justice). Ide-ide tersebut direalisasikan melalui perwujudan simbol-simbol dan hakikat dari nilai-nilai dasar demokrasi, yaitu sungguh-sungguh mewakili atau diangkat dari kenyataan hidup yang sepadan dengan nilai-nilai itu sendiri. ${ }^{28}$ Sejalan dengan hal tersebut, Arbi Sanit menyebutkan tiga nilai ideal yang mendukung demokrasi sebagai suatu gagasan kehidupan, yaitu kemerdekaan (freedom), persamaan (equality), dan keadilan (justice). ${ }^{29}$ Dari uraian di atas, penulis menggunakan prinsip demokrasi yakni kebebasan dan kesetaraan, dengan menganggap keadilan telah termasuk pada persamaan/kesetaraan.

Masih terkait dengan nilai atau prinsip kedaulatan rakyat, Khairul Fahmi memberikan pendapat bahwa prinsip-prinsip kedaulatan rakyat atau demokrasi setidaknya ada empat, dua pertama yaitu: kebebasan dan kesamaan/kesetaraan yang dinamakan sebagai esensi kedaulatan rakyat (prinsip esensial). Dua prinsip lainnya yaitu suara mayoritas dan pertanggungjawaban yang dikategorikan sebagai prosedur pelaksanaan kedaulatan rakyat (prinsip prosedural). ${ }^{30}$ Robert A. Dahl memberikan

\footnotetext{
25 K. Abdul Gafoor, "Validation of Scale of Commitment to Democratic Values among Secondary Students", Guru Journal of Behavioral and Social Sciences, Vol. 3, Issue 1, Januari-Maret 2015, hal. 361-373.

${ }^{26}$ Khairul Fahmi, Prinsip Kedaulatan Rakyat..., ibid., hal. 119-160.

27 Ibid.

28 Titik Triwulan Tutik, Konstruksi Hukum Tata Negara Indonesia Pasca Amandemen UUD 1945, Jakarta: Kencana, 2010, hlm. 70

${ }^{29}$ Ibid., hal. 74.

30 Khairul Fahmi, Prinsip Kedaulatan Rakyat..., ibid., hal. 119-160.
} 
pandangan yang lebih menitikberatkan demokrasi pada aspek kebebasan politik. Dahl mengatakan setidaknya ada 5 (lima) kriteria atau standar sehingga proses pemerintahan dapat dikatakan demokratis. Kriteria tersebut meliputi: (1) Partisipasi efektif; (2) Persamaan suara; (3) Pemahaman yang cerah; (4) Agenda pengawasan; dan (5) Pengikutsertaan orang dewasa. ${ }^{31}$ Masih dalam kaitannya dengan aspek kebebasan politik, Affan Gaffar memberikan paramater untuk mengamati apakah sebuah political order (pemerintahan) merupakan sistem yang demokratis atau tidak. Parameter tersebut yaitu: a) akuntabilitas; b) rotasi kekuasaan; c) rekrutmen politik; d) pemilihan umum; e) adanya pengakuan dan perlindungan hak-hak dasar. ${ }^{32}$

Baik Robert A. Dahl dan Affan Gaffar memberikan kriteria demokrasi yang meskipun berbeda namun masih memiliki kemiripan satu sama lainnya. Namun, Dahl dan Affan Gaffar mencantumkan prinsip pengawasan atau akuntabilitas sebagai syarat demokrasi. Keduanya merupakan sarana pertanggungjawaban dalam penyelenggaraan negara. Terkait hal ini, Miriam Budiardjo menyatakan bahwa salah satu unsur terpenting demokrasi adalah akuntabilitas yaitu pertanggungjawaban dari pihak yang diberi mandat untuk memerintah. ${ }^{33}$ Kedaulatan rakyat memberi kekuasaan yang tertinggi kepada rakyat, tetapi juga meletakkan tanggung jawab yang terbesar. $^{34}$ Institute For Goverment menyatakan bahwa akuntabilitas yang kuat memberikan dasar bagi demokrasi yang sehat. Akuntabilitas merupakan bagian dari tata kelola yang baik, dan dapat meningkatkan kepercayaan dan legitimasi negara di mata publik. ${ }^{35}$ Bahkan USAID menyatakan bahwa proses pemerintahan sangat legitimasi ketika menggabungkan prinsip-prinsip demokrasi seperti transparansi, pluralisme, keterlibatan warga negara dalam pengambilan keputusan, representasi, dan akuntabilitas. ${ }^{36}$

Berdasarkan uraian di atas, penulis berpendapat bahwa prinsip-prinsip kedaulatan rakyat atau demokrasi adalah kebebasan (freedom) dan persamaan

\footnotetext{
31 Ibid.

32 Titik Triwulan Tutik, Konstruksi Hukum...ibid,, hal. 72.

33 Khairul Fahmi, Prinsip Kedaulatan Rakyat..., ibid., hal. 119-160.

34 Mohammad Hatta, Demokrasi Kita, Bandung: Sega Arsy, 2018, hal. 57.

35 Institute For Goverment, 15 Oktober 2018, “Accountability In Modern Government Recommendations For Change", https://www.instituteforgovernment.org.uk/publications/accountability-modern-governmentrecommendations, diakses tanggal 20 Agustus 2021.

36 USAID, 13 Agustus 2021, "Promoting Accountability and Transparency", https://www.usaid.gov/what-wedo/democracy-human-rights-and-governance/promoting-accountability-transparency, diakses tanggal 17 Agustus 2021.
} 
(equality) sebagaimana merupakan kesamaan dari prinsip-prinsip kedaulatan rakyat (demokrasi) yang disampaikan para ahli. Penulis mempertimbangkan prinsip akuntabilitas (accountability) sebagai prinsip ketiga sebagaimana disampaikan Robert A. Dahl, Affan Ghaffar, Miriam Budiardjo, dan Khairul Fahmi. Singkatnya, negara demokrasi harus menjalankan tiga prinsip tersebut. Tiga prinsip ini pula yang menurut penulis sebagai penjelmaan kedaulatan rakyat atau demokrasi dalam kehidupan bernegara.

\section{Kedaulatan Rakyat dalam UUD NRI Tahun 1945}

Pada dasarnya, baik sebelum perubahan, maupun setelah mengalami perubahan dari UUD 1945 menjadi Undang-Undang Dasar Negara Republik Indonesia Tahun 1945 (UUD NRI Tahun 1945), kedaulatan tetap berada di tangan rakyat. Namun perubahan berdampak pada paradigma pelaksanaan kedaulatan rakyat. Sebelum perubahan, rumusan kedaulatan rakyat termuat dalam Pasal 1 ayat (2) UUD 1945 dan berbunyi "Kedaulatan adalah di tangan rakyat, dan dilakukan sepenuhnya oleh Majelis Permusyawaratan Rakyat". Ketentuan tersebut mengandung makna kedaulatan rakyat dan asas permusyawaratan sekaligus. Dengan rumusan kalimat tersebut dimaksudkan bahwa sistem UUD 1945 menganut direct democracy atau demokrasi langsung yaitu pelaksanaan kedaulatan oleh sebuah badan yang disebut Majelis Perusyawaratan Rakyat (MPR). MPR inilah yang merupakan penjelmaan rakyat dan akan memegang kedaulatan rakyat sepenuhnya. ${ }^{37}$

UUD NRI Tahun 1945 merubah konstruksi pelaksanaan kedalatan rakyat. Saldi Isra menyatakan bahwa perubahan UUD 1945 menjadi UUD NRI Tahun 1945 dapat dimaknai sebagai lompatan untuk memulihkan kedaulatan rakyat. ${ }^{38}$ Konstruksi kedaulatan rakyat pada UUD NRI Tahun 1945 yakni "Kedaulatan berada di tangan rakyat dan dilaksanakan menurut Undang-Undang Dasar". ${ }^{39}$ Makna rumusan ini yakni seluruh lembaga negara itu pada dasarnya adalah bagian dari pelaksanaan kedaulatan rakyat sesuai dengan fungsinya masing-masing. Lembaga-lembaga negara tersebut memperoleh kewenangannya langsung dari undang-undang dasar, bukan merupakan pemberian lembaga negara lainnya. Masing-masing lembaga

37 Eduardus Marius Bo, ibid., hal. 125-126.

38 Saldi Isra, Lembaga Negara (Konsep, Sejarah, Wewenang, dan Dinamika Konstitusional), Jakarta: Rajawali Pers, 2020, hal. 144.

39 Pasal 1 ayat (2) UUD NRI Tahun 1945. 
negara memiliki kedudukan sederajat menurut undang-undang dasar yang dalam melaksanakan kewenangannya tunduk pada prinsip saling mengawasi dan saling mengimbangi yang aturannya ditentukan oleh undang-undang dasar. ${ }^{40}$

Frasa "dilaksanakan menurut UUD” mempunyai makna adanya pembatasan dari penggunaan kekuasaan yang bersumber dari kedaulatan. Pembatasan tersebut dibedakan dari dua aspek, yaitu 1) Aspek prosedur, yang artinya bahwa pelaksanaan kedaulatan rakyat harus diikuti prosedur yang ditentukan oleh UUD; dan 2) Aspek substansi, yang artinya bahwa penggunaan kewenangan yang bersumber kedaulatan rakyat tidak tanpa batas, tetapi dibatasi oleh ketentuan konstitusi. ${ }^{41}$ Berdasarkan uraian tersebut, baik secara prosedur dan substansi maka kedaulatan rakyat menurut undang-undang dasar harus dilaksanakan berdasarkan prinsip-prinsipnya. Maka perlu untuk melihat apakah prinsip kebebasan, prinsip persamaan atau kesetaraan dan prinsip akuntabilitas telah diejawantahkan dalam UUD NRI Tahun 1945 sebagai dasar argumentasi bahwa konstitusi Indonesia telah melaksanakan kedaulatan rakyat atau demokrasi.

a. Prinsip kebebasan

Kebebasan berada dalam suatu sistem sosial yaitu masyarakat dan negara. Dalam konteks ini, perlu untuk melihat pendapat Jhon Stuart Mill terkait kebebasan yakni "the nature and limits of the power which can be legitimately exercised by society over the individual". ${ }^{42}$ Bagi Mill, kebebasan merupakan sifat dan batas kekuasaan yang dapat dilaksanakan secara sah dan legitimasi oleh masyarakat dan negara atas individu-individu di dalamnya. Manusia adalah bebas karena ia sendiri dapat mengembangkan pikiran tentang tujuan-tujuan dan sarana-sarana kehidupannya dan sejauh ia dapat mencoba untuk bertindak sesuai dengan pikiran tersebut. ${ }^{43}$ Kebebasan yang dimaksud bukanlah kebebasan yang tiada batas. Terkait hal ini kita dapat melihat pendapat Jhon Locke yang menyatakan bahwa kebebasan bergantung pada kebutuhan untuk mencari kebahagiaan yang sebenarnya dan pada

\footnotetext{
40 I Dewa Gede Palguna, "Perspektif Teoritik Eksistensi Mahkamah Konstitusi (Pasca Perubahan Uud 1945)", Jurnal Konstitusi Mahkamah Konstitusi, Vol. 2, No. 3, November 2005, hal. 8-15.

41 Eduardus Marius Bo, ibid., hal. 207.

42 Jhon Stuart Mill, On Liberty, Ontario: Batoche Books Limited, 2001, hal. 6.

43 Franz Magnis Suseno, Etika Politik (Prinsip Moral Dasar Kenegaraan Modern), Jakarta: Gramedia Pustaka Utama, 2018, hal. 12.
} 
pengendalian hasrat manusia. Locke dengan tegas menyatakan bahwa pengendalian hasrat-hasrat manusia adalah kemajuan yang benar dari kebebasan. ${ }^{44}$

Berdasarkan pendapat Jhon Locke tersebut, kebebasan merupakan hasrat yang mesti dikendalikan sehingga tidak menganggu tatanan sosial dimana kebebasan itu berada. Namun bagaimana cara mengendalikan kebebasan? Terkait hal ini Jhon Rawls menjelaskan bahwa kebebasan terkait tiga hal, yakni individual yang bebas, batasan atau larangan yang dibebaskan dari individual tersebut, dan apa yang bebas atau tidak boleh individu tersebut lakukan. ${ }^{45}$ Batasan bisa bervariasi mulai dari kewajiban dan larangan yang ditetapkan oleh hukum hingga pengaruh memaksa yang timbul dari opini publik dan tekanan sosial. ${ }^{46}$ Dalam hubungannya dengan batasan-batasan konstitusional dan hukum, kebebasan menjadi struktur institusi tertentu dan sebuah sistem tertentu dari aturan-aturan publik yang menentukan hak dan kewajiban. ${ }^{47}$ Terkait hal ini maka muncullah salah satu fungsi hukum sebagai penjamin kebebasan, yakni sebagai pelindung kebebasan individu dan pembatasan kebebasan untuk melindungi jaminan kebebasan individu lainnya. ${ }^{48}$ Batasan melalui hukum sebagai penjamin kebebasan berlangsung dalam konteks bernegara sehingga kebebasan sampai pada kondisi dimana bukan hanya individu-individu yang dibolehkan untuk melakukan atau tidak melakukan sesuatu, tapi pemerintah dan orang lain juga harus mempunyai kewajiban hukum untuk tidak merintanginya. ${ }^{49}$ Sejalan dengan hal tersebut, Hans Kelsen menyatakan bahwa kebebasan yang mungkin didapat dalam masyarakat, dan khususnya di dalam negara, tidak bisa berupa kebebasan dari setiap ikatan, tetapi hanya bisa berupa kebebasan dari suatu macam ikatan tertentu. ${ }^{50}$ Jadi kebebasan tidak dapat absolut namun perlu pengaturan-pengaturan agar tidak terjadi suatu anarki.

UUD NRI Tahun 1945 menyatakan kedaulatan berada di tangan rakyat dan dilaksanakan menurut Undang-Undang Dasar, dengan begitu maka prinsip kebebasan harus terlaksana didalamnya. Maka menjadi pertanyaan, bagaimana

\footnotetext{
44 Bertrand Russell, Sejarah Filsafat.., ibid., hal. 804.

45 Jhon Rawls, Teori Keadilan (Prinsip-Prinsip Filsafat Politik untuk Mewujudkan Kesejahteraan Sosial Dalam Negara), Yogyakarta: Pustaka Pelajar, 2011, hal. 253.

46 Ibid., hal. 254.

47 Ibid.

48 Franz Magnis Suseno, ibid., hal. 149.

49 Jhon Rawls, Loc. Cit.

50 Hans Kelsen, Teori Umum Tentang Hukum Dan Negara, Bandung: Nusamedia, 2016, hal. 406.
} 
prinsip kebebasan itu dilaksanakan? Atas hal ini kita dapat melihat pembukaan UUD NRI Tahun 1945. Pembukaan UUD NRI Tahun 1945 alinea pertama menyatakan bahwa "Bahwa sesungguhnya Kemerdekaan itu ialah hak segala bangsa dan oleh sebab itu, maka penjajahan di atas dunia harus dihapuskan, karena tidak sesuai dengan perikemanusiaan dan peri-keadilan." Kalimat tersebut menunjukkan pengakuan dan pengagungan kebebasan melalui hak kemerdekaan suatu bangsa atas penjajahan. Selain itu, jika dihubungkan dengan pendapat Jhon Rawls bahwa dalam konteks batasan-batasan konstitusional dan hukum, kebebasan menjadi struktur institusi tertentu dan sebuah sistem tertentu dari aturan-aturan publik yang menentukan hak dan kewajiban, maka UUD NRI Tahun 1945 mengatur pula aturanaturan publik mengenai hak dan kewajiban. Terkait hak dan kewajiban warga negara ini tercantum dalam pasal 27 sampai dengan pasal 34 UUD NRI Tahun 1945. ${ }^{51}$ Selain itu, Yusuf Muhammad menyatakan bahwa pengaturan materi hak asasi manusia merupakan wujud dan egaliterianisme dalam melaksanakan kehidupan berbangsa dan bernegara. ${ }^{52}$ Misalnya keberadaan Pasal 28I ayat (4) UUD NRI Tahun 1945 sebagai ketentuan bagi pemerintah untuk melindungi, memajukan, menegakkan dan memenuhi HAM setiap warga negara. ${ }^{53}$ Keberadaan jaminan hak asasi manusia, mutatis mutandis UUD NRI Tahun 1945 telah menerapkan dan menganut dua prinsip kedaulatan rakyat, yakni kebebasan dan persamaan. ${ }^{54}$ Kebebasan dalam kerangka batasan-batasan konstitusional dan hukum pada aturan-aturan terkait hak dan kewajiban tersebut misalnya Pasal 28,55 Pasal 28E,56 Pasal 28G ayat (2),57

\footnotetext{
51 Mahkamah Konstitusi Republik Indonesia, 11 Agustus 2015, "Hak Dan Kewajiban Warga Negara Indonesia Dengan UUD 45", https://www.mkri.id/index.php?page=web.Berita\&id=11732, diakses tanggal 20 Agustus 2021.

52 Yusuf Muhammad merupakan anggota MPR dari F-KB dan hal ini disampaikan dalam proses pembahasan materi HAM pada rapat PAH I BP MPR tanggal 9 Desember 1999. Ibid., hal. 141.

53 Pasal 28I ayat (4) menyatakan "Perlindungan, pemajuan, penegakan, dan pemenuhan hak asasi manusia adalah tanggung jawab negara, terutama pemerintah."

${ }^{54}$ Khairul Fahmi, Prinsip Kedaulatan Rakyat..., ibid., hal. 119-160.

55 Pasal 28 UUD NRI Tahun 1945 menyatakan "Kemerdekaan berserikat dan berkumpul, mengeluarkan pikiran dengan lisan dan tulisan dan sebagainya ditetapkan dengan undang-undang."

56 Pasal 28E UUD NRI Tahun 1945 menyatakan "(1) Setiap orang bebas memeluk agama dan beribadat menurut agamanya, memilih pendidikan dan pengajaran, memilih pekerjaan, memilih kewarganegaraan, memilih tempat tinggal di wilayah negara dan meninggalkannya, serta berhak kembali. (2) Setiap orang berhak atas kebebasan meyakini kepercayaan, menyatakan pikiran dan sikap, sesuai dengan hati nuraninya. (3) Setiap orang berhak atas kebebasan berserikat, berkumpul, dan mengeluarkan pendapat."

57 Pasal 28G ayat (2) UUD NRI Tahun 1945 menyatakan "Setiap orang berhak untuk bebas dari penyiksaan atau perlakuan yang merendahkan derajat martabat manusia dan berhak memperoleh suaka politik dari negara lain."
} 
dan Pasal 28I ayat (2) 58 $^{58}$ erupakan sebagian ketentuan UUD NRI Tahun 1945 yang menjamin setiap untuk menikmati kebebasan sebagai manusia. ${ }^{59}$ Berdasarkan uraian tersebut maka jelaslah bahwa prinsip kebebasan sebagai perwujudan kedaulatan rakyat dianut oleh UUD NRI Tahun 1945.

\section{b. Prinsip persamaan/kesetaraan}

Persamaan/kesetaraan juga merupakan keyakinan bahwa tidak seorang pun seharusnya memiliki kesempatan hidup yang lebih buruk karena cara mereka dilahirkan, dari mana mereka berasal, apa yang mereka yakini, atau apakah mereka memiliki disabilitas. ${ }^{60}$ Persamaan merupakan prinsip yang tidak dapat dipisahkan dengan prinsip kebebasan. Dengan prinsip kebebasan, berarti setiap manusia merdeka untuk mengapresiasikan kebebasannya. Dan dengan demikian, semua individu tentunya mempunyai nilai politik yang sama dan bahwa setiap orang mempunyai tuntutan yang sama atas kebebasannya. ${ }^{61}$ Demokrasi mengharuskan orang-orang diperlakukan sama sejauh mereka adalah otonom dalam proses pemerintahan, otonom dalam hal ini terkait terkait dengan praktik penentuan nasib sendiri. Bentuk kesetaraan ini mendasar bagi demokrasi karena merupakan bagian dari definisi demokrasi itu sendiri. ${ }^{62}$ Terkait hal ini Amy Gutman menyatakan “When I use the term democracy, it signifies a political commitment to the civil equality of individuals." Baginya, kata demokrasi itu sendiri menandakan komitmen politik terhadap kesetaraan sipil dan individu. ${ }^{63}$ Pelaksanaan sistem demokrasi biasanya diasumsikan menerapkan kebebasan dan kesetaraan sebagai nilai kunci dan terpenting. Sebagaimana juga pandangan Gutman, ketika terdapat pertanyaan tentang pengertian demokrasi, kebanyakan orang mengacu pada salah satu dari dua nilai tersebut atau campuran dari keduanya. Para ahli juga menunjukkan bahwa demokrasi adalah satu-satunya rezim di mana warga negara lebih bebas dan lebih

\footnotetext{
58 Pasal 28I ayat (2) UUD NRI Tahun 1945 menyatakan "Setiap orang berhak bebas dari perlakuan yang bersifat diskriminatif atas dasar apa pun dan berhak mendapatkan perlindungan terhadap perlakuan yang bersifat diskriminatif itu."

${ }^{59}$ Khairul Fahmi, Prinsip Kedaulatan Rakyat..., ibid., hal. 119-160.

${ }^{60}$ Equality and Human Rights Comission, 02 Agustus 2018, "Understanding Equality", https://www.equalityhumanrights.com/en/secondary-education-resources/useful-information/understandingequality, diakses tanggal 22 Agustus 2021.

61 Khairul Fahmi, Prinsip Kedaulatan Rakyat..., ibid., hal. 119-160.

62 Robert Post, "Democracy and Equality", The ANNALS of the American Academy of Political and Social Science, Vol. 603, No. 1, January 2006, hal. 24-36.

63 Ibid.
} 
setara daripada di negara lain mana pun. ${ }^{64}$ Kesetaraan dalam demokrasi merupakan gagasan bahwa suatu keharusan untuk memperlakukan orang secara setara, dalam konteks negara berarti semua warga negara harus diperlakukan sebagai warga negara yang setara.

Ronald Dworkin memiliki pandangan tersendiri terhadap kesetaraan. Menurutnya, pemerintah memiliki kewajiban untuk memperlakukan setiap orang secara setara, dengan perhatian dan rasa hormat yang sama. Dengan memperlakukan seseorang secara setara, maka pemerintah memperlakukan setiap warganya dengan martabat yang sama, menganggapnya sebagai individu yang berkepentingan untuk menjalani kehidupan yang benar-benar baik. ${ }^{65}$ Dalam konteks negara demokrasi, Elizabeth S. Anderson memberikan teori yang dinamakannya sebagai democratic equaltiy. Anderson menyatakan bahwa "...democratic equality integrates principles of distribution with the expressive demands of equal respect." Kesetaraan demokratis menjamin akses yang efektif setiap saat bagi semua warga negara yang taat hukum, suatu kebebasan dalam kondisi sosial apapun. Prinsip persamaan adalah tentang memastikan bahwa setiap individu memiliki kesempatan yang sama untuk memaksimalkan hidup dan bakat mereka namun dengan tidak meninggalkan kewajiban mereka sebagai warga negara. ${ }^{66}$ Berdasarkan uraian tersebut terlihat pentingnya peran negara dalam memberikan jaminan terhadap persamaan atau kesetaraan (equality).

Oleh karena itu, patut dilihat bagaimana UUD NRI Tahun 1945 mewujudkan prinsip persamaan tersebut. Prinsip persamaan atau kesetaraan (equality) setidaknya ditemukan pada Pasal 28D ayat (1), ${ }^{67}$ Pasal 28H ayat (2), ${ }^{68}$ Pasal 28I ayat (2). ${ }^{69}$ Ketentuan dalam UUD NRI Tahun 1945 merupakan dasar yang menjamin bahwa setiap rakyat mesti mendapatkan perlakukan sama, tanpa diskriminasi. Prinsip persamaan yang diatur dalam UUD NRI Tahun 1945 lebih banyak

\footnotetext{
64 Leonardo Molino, Equality, Freedom, and Democracy (Europe After the Great Recession), New York: Oxford Unversity Press, 2020, hal. 1.

65 J.S. Andrews, "Liberal Equality and the Justification of Multicultural, Civic Education." Canadian Journal of Law \& Jurisprudence, Vol. 7, No. 1, Juni 1994, hal 26-111.

66 Elizabeth S. Anderson, "What is the Point of Equality?", Ethics, Vol. 109, No. 2, Januari 1993, hal. 287-337.

67 Pasal 28D ayat (1) menyatakan "Setiap orang berhak atas pengakuan, jaminan, perlindungan, dan kepastian hukum yang adil serta perlakuan yang sama dihadapan hukum."

68 Pasal 28H ayat (2) menyatakan "Setiap orang berhak mendapat kemudahan dan perlakuan khusus untuk memperoleh kesempatan dan manfaat yang sama guna mencapai persamaan dan keadilan."

${ }^{69}$ Pasal 28I ayat (2) menyatakan "Setiap orang bebas dari perlakuan yang bersifat diskriminatif atas dasar apapun dan berhak mendapatkan perlindungan terhadap perlakuan yang bersifat diskriminatif itu."
} 
menekankan pada aspek persamaan di hadapan hukum. Pertimbangannya adalah, disamping sebagai salah satu prinsip kedaulatan rakyat, persamaan di depan hukum juga merupakan satu prinsip hak asasi manusia. ${ }^{70}$ Adanya jaminan hak asasi manusia maka mutatis mutandis UUD NRI Tahun 1945 telah menerapkan sekaligus menganut dua prinsip kedaulatan rakyat, yakni kebebasan dan persamaan. ${ }^{71}$

c. Prinsip pertanggungajawaban atau akuntabilitas (accountability)

Akuntabilitas merupakan salah satu pilar pemerintahan yang baik (good governance).$^{72}$ Prinsip akuntabilitas (accountabiltity) merupakan konsep yang sangat berkembang dalam sistem negara demokrasi. Terdapat kaitan yang erat pula antara kewenangan dan akuntabilitas. Pada dasarnya setiap tindakan organ pemerintah berdasarkan kewenangan dan pertanggungjawaban, sebagaimana asas "geen bevoegheid zonder varantwoordelijkheid" yang berarti tidak ada kewenangan tanpa pertanggungjawaban atau asas "zonder bevoegdheid geen verantwoordelijkheid" yang berarti tanpa kewenangan tidak ada pertanggungjawaban. Secara umum, setiap tindakan organ pemerintahan adalah penggunaan wewenang, oleh karena itu selalu terkait dengan pertanggungjawaban. Setiap penggunaan kewenangan apapun bentuknya apakah dalam rangka pengaturan, pengawasan, maupun penentuan sanksi oleh badan pemerintah selalu disertai dengan adanya tanggung jawab (akuntabilitas). ${ }^{73}$ Akuntabilitas merupakan prinsip di mana seseorang atau lembaga bertanggung jawab atas serangkaian tugas dan dapat diminta untuk memberikan pertanggungjawaban pemenuhannya kepada otoritas yang berada dalam posisi untuk memberikan penghargaan atau hukuman. ${ }^{74}$

Akuntabilitas pada sektor publik atau pemerintahan menjadi tuntutan sistem demokrasi dalam bentuk transparansi dan pemberian informasi kepada publik sebagai jaminan pemenuhan akan hak-hak publik. Penulis berpendapat bahwa Akuntabilitas mencakup makna pertanggungjawaban para wakil rakyat di parlemen, pertanggungjawaban pemerintah, bahkan pertanggungjawaban hukum. Hal ini

\footnotetext{
70 Khairul Fahmi, “Prinsip Kedaulatan Rakyat...”, ibid., hal. 119-160.

71 Ibid.

72 Nana Sukarna, "Audit dan Akuntablitas Pengelolaan Keuangan Daerah", dalam Abdul Halim dan Muhammad Iqbal (ed.), Pengelolaan Keuangan Daerah, (Yogyakarta: UPP STIM YKPN, 2019), hal. 35.

73 Alan Bayu Aji, "Implikasi Politik Hukum Pengaturan Pertanggungjawaban Kinerja Kepala Daerah Pasca Reformasi", Lex Rennaisance, Vol. 2, No. 2, Juli 2017, hal. 231 - 258.

${ }^{74}$ Dario Castiglione, 22 Oktober 2012, "Accountability", Encyclopedia Britannica, https://www.britannica.com/topic/accountability, diakses tanggal 28 Agustus 2021.
} 
sejalan dengan Dario Castiglione yang menyatakan bahwa “...accountability was part of a family of words in English that covered a number of interrelated meanings that had to do with issues of political representation, executive and administrative responsibility, and, more loosely, legal liability."75

Akuntabilitas mencakup dimensi horizontal dan vertikal. Dimensi horizontal adalah sistem checks and balances antara cabang eksekutif, legislatif dan yudikatif. Akuntabilitas vertikal merupakan hubungan antara warga negara dan pembuat keputusan, termasuk kemampuan warga negara untuk memengaruhi proses pengambilan keputusan politik, dengan kata lain sebagai pertanggungjawaban kepada masyarakat. ${ }^{76}$ Dengan penekanan pada hubungan antara negara dan warga negara maka akuntabilitas vertikal tidak melulu melalui proses pengambilan keputusan politik yang terpaku pada pemilihan umum, melainkan juga lewat pemberian kesempatan seluas-luasnya lewat aspirasi masyarakat terhadap pelaksanaan kewenangan setiap organ negara kapanpun rakyat mengiginkannya. Pertanggungjawaban kepada masyarakat di samping merupakan kewajiban adalah tugas wajarnya yang dilakukan karena rakyat adalah pemegang kedaulatan tertinggi negara sesuai dengan Undang-Undang Dasar Negara Republik Indonesia Tahun 1945.77

Prinsip dasar akuntabilitas pada negara negara demokrasi berupa pertanggungjawaban kepada rakyat/masyarakat (societas/society) selaku pemberi mandat untuk mengelola negara. Maka, pertanggungjawaban dalam dimensi vertikal meliputi pula pertanggungjawaban hukum karena melekatnya hukum pada masyarakat (societas/society). Hal ini sangat beralasan terutama jika melihat perkembangan definisi accountability yang juga mencakup legal liability sebagaimana disampaikan oleh Dario Castiglione serta prinsip negara hukum dalam bentuk constitutional democracy. Berdasarkan uraian tersebut, kita dapat melihat bahwa akuntabilitas menghendaki bahwa setiap pelaksanaan tugas dan hasil akhir dari kegiatan pemerintahan dan pembangunan harus dapat dan wajib dipertanggungjawabkan dengan sebaik-baiknya pada masyarakat dan para pihak

\footnotetext{
75 Dario Castiglione, ibid.

76 OECD, DAC Guidelines and Reference Series: Accountability and Democratic Governance (Orientations and Principles for Development), Paris: OECD Publishing, hal. 23.

77 Fajlurrahman Jurdi, Hukum Tata Negara Indonesia, Jakarta: Prenadamedia Group, 2019, hal. 75-76.
} 
yang terkait, misalnya dalam dimensi akuntabilitas vertikal dan horizontal, sesuai dengan peraturan perundang-undangan. ${ }^{78}$

Dalam konteks UUD NRI Tahun 1945, akuntabilitas dalam dimensi horizontal dapat dilihat setidaknya namun tidak terbatas pada: 1) ketentuan mengenai impeachment Presiden; ${ }^{79}$ 2) ketentuan pembentukan undang-undang; ${ }^{80}$ 3) ketentuan mengenai fungsi Dewan Perwakilan Rakyat;81 4) ketentuan mengenai hak Presiden dalam menetapkan peraturan pemerintah sebagai pengganti undang-undang; ${ }^{82}$ 5) ketentuan mengenai kewenangan Dewan Perwakilan Daerah;83 6) ketentuan mengenai Anggaran Pendapatan dan Belanja Negara;84 7) ketentuan mengenai kewenangan Badan Pemeriksa Keuangan; ${ }^{55}$ 8) ketentuan mengenai pemilihan anggota Badan Pemeriksa Keuangan; ${ }^{86}$ 9) ketentuan mengenai kewenangan Mahkamah Agung;87 10) ketentuan mengenai pemilihan Hakim Agung; ${ }^{88}$ 11) ketentuan mengenai kewenangan Komisi Yudisial; ${ }^{89}$ dan 12) ketentuan mengenai kewenangan dan kewajiban Mahkamah Konstitusi. ${ }^{90}$ Selain ketentuan pada UUD NRI Tahun 1945, tentunya terdapat berbagai mekanisme check and balances pada berbagai instrumen peraturan perundang-udangan sebagai sarana akuntabillitas horizontal dalam praktik bernegara di Indonesia.

\footnotetext{
78 OECD, ibid., hal. 23.

79 Pasal 7A dan Pasal 7B UUD NRI Tahun 1945.

80 Pasal 20 UUD NRI Tahun 1945.

81 Pasal 20A UUD NRI Tahun 1945.

82 Pasal 22 UUD NRI Tahun 1945.

83 Pasal 22D UUD NRI Tahun 1945.

84 Pasal 23 UUD NRI Tahun 1945.

85 Pasal 23E UUD NRI Tahun 1945.

86 Pasal 23F UUD NRI Tahun 1945.

87 Pasal 24A ayat (1) UUD NRI Tahun 1945.

88 Pasal 24A ayat (3) UUD NRI Tahun 1945.

89 Pasal 24 B ayat (1) UUD NRI Tahun 1945.

90 Pasal 24 C ayat (1) dan ayat (2) UUD NRI Tahun 1945.
} 
Dimensi akuntabilitas vertikal dalam UUD NRI Tahun 1945 dapat dilihat setidaknya namun tidak terbatas pada ketentuan Pasal 1 ayat (2),91 Pasal 6A,92 Pasal 7,93 Pasal 18 ayat (3) dan ayat (4), ${ }^{94}$ Pasal 19 ayat (1), ${ }^{95}$ Pasal 22C ayat (1), ${ }^{96}$ dan Pasal 22E. ${ }^{97}$ Dan jika terkait dengan pertanggungjawaban hukum, setidaknya namun tidak terbatas pada ketentuan-ketentuan Pasal 1 ayat (3),98 Pasal 3 ayat (3),99 Pasal 7A,100 Pasal 22B,101 Pasal 22D ayat (4). ${ }^{102}$ Beberapa ketentuan tersebut memuat pemberhentian pengisi jabatan yang dipilih publik melalui pemilihan umum ketika melakukan pelanggaran hukum. Pertanggungjawaban hukum juga berlaku pada jabatan publik yang tidak diisi melalui pemilihan umum. Hal ini, meskipun diatur dalam instrumen hukum diluar undang-undang dasar, tetap dipandang sebagai bentuk pelaksanaan pertanggungjawaban hukum yang dibenarkan dan diamanatkan oleh UUD NRI Tahun 1945.

Maka berdasarkan uraian di atas, tidak keliru jika penulis menegaskan bahwa UUD NRI Tahun 1945 menerapkan prinsip pertanggungjawaban atau akuntabilitas (accountability). Prinsip ini tentunya sebagaimana juga prinsip kebebasan (freedom)

\footnotetext{
91 Pasal 1 ayat (2) UUD NRI Tahun 1945 menyatakan "Kedaulatan berada di tangan rakyat dan dilaksanakan menurut Undang-Undang Dasar."

92 Pasal 6A UUD NRI Tahun 1945 menyatakan "Presiden dan Wakil Presiden dipilih dalam satu pasangan secara langsung oleh rakyat."

93 Pasal 7 UUD NRI Tahun 1945 menyatakan "Presiden dan Wakil Presiden memegang jabatan selama lima tahun, dan sesudahnya dapat dipilih kembali dalam jabatan yang sama, hanya untuk satu kali masa jabatan."

94 Pasal 18 ayat (3) dan ayat (4) UUD NRI Tahun 1945 menyatakan "(3) Pemerintahan daerah provinsi, daerah kabupaten, dan kota memiliki Dewan Perwakilan Rakyat Daerah yang anggotaanggotanya dipilih melalui pemilihan umum. (4) Gubernur, Bupati, dan Walikota masingmasing sebagai kepala pemerintah daerah provinsi, kabupaten, dan kota dipilih secara demokratis."

95 Pasal 19 ayat (1) UUD NRI Tahun 1945 menyatakan "Anggota Dewan Perwakilan Rakyat dipilih melalui pemilihan umum."

96 Pasal 22C ayat (1) menyatakan "Anggota Dewan Perwakilan Daerah dipilih dari setiap provinsi melalui pemilihan umum."

97 Pasal 22E ayat (1), ayat (2), ayat (3), ayat (4), dan ayat (5) UUD NRI Tahun 1945 menyatakan "(1) Pemilihan umum dilaksanakan secara langsung, umum, bebas, rahasia, jujur, dan adil setiap lima tahun sekali. (2) Pemilihan umum diselenggarakan untuk memilih anggota Dewan Perwakilan Rakyat, Dewan Perwakilan Daerah, Presiden dan wakil presiden dan Dewan Perwakilan Rakyat Daerah. (3) Peserta pemilihan umum untuk memilih anggota Dewan Perwakilan Rakyat dan anggota Dewan Perwakilan Rakyat Daerah adalah partai politik. (4) Peserta pemilihan umum untuk memilih anggota Dewan Perwakilan Daerah adalah perseorangan. (5) Pemilihan umum diselenggarakan oleh suatu komisi pemilihan umum yang bersifat nasional, tetap, dan mandiri."

98 Pasal 1 ayat (3) menyatakan "Negara Indonesia adalah negara hukum."

99 Pasal 3 ayat (3) menyatakan "Majelis Permusyawaratan Rakyat hanya dapat memberhentikan Presiden dan/atau Wakil Presiden dalam masa jabatannya menurut UndangUndang Dasar."

100 Pasal 7A menyatakan "Presiden dan/atau Wakil Presiden dapat diberhentikan dalam masa jabatannya oleh Majelis Permusyawaratan Rakyat atas usul Dewan Perwakilan Rakyat, baik apabila terbukti telah melakukan pelanggaran hukum berupa pengkhianatan terhadap negara, korupsi, penyuapan, tindak pidana berat lainnya, atau perbuatan tercela maupun apabila terbukti tidak lagi memenuhi syarat sebagai Presiden dan/atau Wakil Presiden." 101 Pasal 22B menyatakan "Anggota Dewan Perwakilan Rakyat dapat diberhentikan dari jabatannya, yang syaratsyarat dan tata caranya diatur dalam undang-undang."

102 Pasal 22D ayat (4) menyatakan "Anggota Dewan Perwakilan Daerah dapat diberhentikan dari jabatannya, yang syarat-syarat dan tata caranya diatur dalam undang-undang."
} 
dan persamaan atau kesetaraan (equality) termuat juga dalam instrumen peraturan perundang-undangan di bawah undang-undang dasar. Namun harus dilihat sebagai bagian yang tidak terpisahkan dari perwujudan kedaulatan rakyat dalam undangundang dasar dan tidak dapat bertentangan terhadapnya (inkonstitusional).

\subsection{Pengaruh Kedaulatan Rakyat Terhadap Hubungan DPRD dengan BPK}

\section{Akuntabilitas Keuangan Negara}

Tiga prinsip yakni kebebasan (freedom), kesetaraan atau persamaan (equality) dan pertanggungjawaban (accountability) hadir dalam UUD NRI Tahun 1945 sebagai perwujudan kedaulatan rakyat. Namun dalam kaitannya dengan keuangan negara, sebagai hal yang mendasari hubungan antara DPRD dan BPK, maka prinsip pertanggungjawaban (accountability) menjadi bahasan pokok. Hal ini tidak terlepas hubungan kewenangan antar lembaga negara sehingga menimbulkan hubungan timbal balik berdasarkan kewenangan yang dimilikinya tersebut. Luasnya konsep pertanggungjawaban atau akuntabilitas, bagaimanapun mencakup akuntabilitas pengelolaan keuangan negara oleh organ-organya.

Pengelolaan keuangan negara dan bentuk tanggung jawab (akuntabilitas) melalui pemeriksaan keuangan negara merupakan bagian dari akuntabilitas sebagai perwujudan kedaulatan rakyat dalam UUD NRI Tahun 1945. Dalam kaitannya dengan hal ini, Robert D. Lee menyatakan “... a democracy, budgeting is adevice for limiting the powers of government. Two issue in the evolution of modern publik budgeting as an instrument of accountability to whom and for what purposes". ${ }^{103}$ Berdasarkan hal tersebut, tujuan pemeriksaan keuangan negara tidak lain adalah memastikan mandat pengelolaan uang negara tidak lain untuk kepentingan rakyat yang berdaulat. Keuangan negara merupakan salah satu unsur pokok dalam penyelenggaraan pemerintah negara dan memiliki manfaat yang sangat penting guna mewujudkan tujuan negara untuk mencapai masyarakat yang adil makmur dan sejahtera sebagaimana diamanatkan dalam pembukaan UUD NRI Tahun 1945.104

Perubahan UUD 1945 menjadi UUD NRI Tahun 1945 berdampak pada redefinisi keuangan negara. Jika sebelum perubahan keuangan negara dimaknai

103 M. Syarif Nuh, "Hakikat Pertanggungjawaban Pemerintah Daerah dalam Penyelenggaraan Pemerintahan", Masalah-Masalah Hukum, Vol. 41, No. 1, Januari 2012, hal. 50-58.

104 Konsideran UU No. 15 Tahun 2006 tentang Badan Pemeriksa Keuangan. 
sebagai pengelolaan APBN maka setelah perubahan keuangan negara dimaknai semua hak dan kewajiban negara yang dapat dinilai dengan uang serta segala sesuatu baik berupa uang maupun berupa barang yang dapat dijadikan milik negara berhubungan dengan pelaksanaan hak dan kewajiban tersebut. ${ }^{105} \mathrm{Hal}$ ini tidak lepas dan saling terkait dari lingkup keuangan negara yang meluas, khususnya hingga mencakup pengelolaan APBD dan perusahaan yang juga dibiayai oleh APBD. Ketika UUD 1945 pasca perubahan mengatur bahwa hasil pemeriksaan keuangan negara diserahkan pula kepada DPRD maka hal ini bukan dalam konteks pengelolaan APBN. Pengelolaan APBN merupakan kekuasaan pemerintah pusat maka tanggung jawabnya (akuntabilitas) melekat pada pemerintah pusat. Maka, hasil pemeriksaan keuangan negara yang dimaksud adalah pengelolaan APBD dalam rangka desentralisasi.

Akuntabilitas keuangan negara di daerah terlihat melalui kewenangan DPRD dalam pengelolaan keuangan daerah, terwujud dalam fungsi pengawasan yang dimilikinya. Peran penting DPRD dalam pengelolaan keuangan daerah, khususnya penerapan fungsi pengawasan disebabkan 3 (tiga) hal, yakni: (1) fungsi pengawasan anggaran terikat dengan kinerja pengelolaan keuangan, terikat dengan sistem akuntansi pengelolaan anggaran, serta terikat pula dengan akuntabilitas pengelolaan keuangan anggaran yang pengaturannya bersumber dari undang-undang; (2) DPRD merupakan lembaga legislatif daerah sehingga pengawasan yang dilakukan merupakan pengawasan bercorak legislatif (legislative control); (3) pengawasan anggaran terikat dengan jumlah anggaran yang digunakan, program yang dilaksanakan, serta hasil/output yang dicapai. 106

Pengawasan DPRD kemudian dapat diterapkan dalam 3 bentuk, yaitu control of executive, control of expenditure, serta control of taxation. Control of executive merupakan pengawasan terhadap jalannya roda pemerintahan, control of expenditure merupakan pengawasan terhadap pengeluaran dalam rangka roda pemerintahan, serta control of taxation merupakan persetujuan atas penetapan

105 Pasal 1 Angka 1 Undang-Undang Republik Indonesia Nomor 17 Tahun 2003 tentang Keuangan Negara; 106 Hendra Karianga, Politik Hukum dalam Pengelolaan Keuangan Daerah, Jakarta: Prenadamedia Group, 2015, hal. 317. 
beban kepada rakyat, misalnya dalam wujud pajak. ${ }^{107}$ Berdasarkan uraian tersebut, baik BPK dan DPRD secara mandiri memiliki kewenangan dalam rangka pelaksanaan prinsip akuntabilitas sebagai perwujudan kedauaatan rakyat. Sehingga hubungan keduanya sangat terpengaruh dan tidak terlepas dari pelaksanaan kedaulatan rakyat khususnya prinsip akuntabilitas.

\section{Akuntabilitas dalam Hubungan DPRD dengan BPK}

Prinsip akuntabilitas merupakan perwujudan kedaulatan rakyat sehingga cukup beralasan jika pelaksanaannya melalui instrumen hukum dipengaruhi oleh kedaulatan rakyat (demokrasi). Keberadaan BPK sesungguhnya memperkuat pelaksanaan demokrasi. Dalam negara demokrasi harus jelas bagaimana Negara itu memperoleh uang untuk mengatur hidup dan pembangunan masyarakat, darimana sumber-sumber biaya diperoleh dan digunakan untuk apa. Hal tersebut harus ditentukan dan disetujui oleh rakyat, yang dalam hal ini adalah Dewan Perwakilan Rakyat (DPR). Itulah sebabnya, APBN harus dituangkan dalam bentuk undangundang. Sehingga terlihat bahwa kebijaksanaan keuangan dan pengurusan rumah tangga Negara telah diatur oleh rakyat sendiri. Hal yang sama terjadi pada penyusunan APBD. ${ }^{108}$

Namun, pengaturan kebijakan dan pemberian arah saja belum cukup, yang tidak kalah pentingnya adalah apakah hal tersebut telah dilaksanakan oleh pemerintah dengan sebaik-baiknya menurut tujuan semula. Dalam rangka tujuantujuan tersebut diadakan Badan Pemeriksa Keuangan yang bertugas memeriksa pertanggungjawaban pemerintah tentang keuangan Negara dan memeriksa semua pelaksanaan Anggaran Pendapatan dan Belanja Negara. ${ }^{109}$ Pengawasan yang dilakukan BPK termasuk kontrol pengawasan ekstern karena pengawasan tersebut dilakukan oleh BPK sebagai badan independen. ${ }^{110}$

107 Zulkarnain Ridlwan, "Cita Demokrasi Indonesia dalam Politik Hukum Pengawasan Dewan Perwakilan Rakyat terhadap Pemerintah", Jurnal Konstitusi Fakultas Hukum Universitas Lampung, Vol. 12, No. 2, Juni 2015, hal. 305327.

108 Gilang Prama Jasa dan Ratna Herawati, “Dinamika Relasi Antara Badan Pemeriksa Keuangan Dan Dewan Perwakilan Rakyat Dalam Sistem Audit Keuangan Negara”, Jurnal Law Reform, Vol. 13, No. 2, September 2017, hal. 189-203.

109 Ibid.

110 Desyari Azhimy Wiyaliyanti, Untung Dwi Hananto dan Henny Juliani, "Hubungan Kerja Badan Pemeriksa Keuangan Pusat Dengan Badan Pemeriksa Keuangan Perwakilan Provinsi Jawa Tengah Dalam Memeriksa Pengelolaan Dan Pertanggungjawaban Keuangan Di Daerah", Diponegoro Law Journal, Vol. 5, No. 3, Juni 2015, hal. $1-7$. 
Hal ini yang menjadi pondasi dasar atau keinginan dari prinsip akuntabilitas. Pelaksanaan akuntabilitas keuangan negara memiliki dimensi horizontal dan vertikal. Dimensi akuntabilitas horizontal dimaknai dalam kedudukan BPK sebagai lembaga pemeriksa pengelolaan dan tanggung jawab keuangan negara terhadap lembaga negara lainnya. Atas dasar itu, BPK lewat kewenangannya menjadi check and balances atas pengelolaan dan tanggung jawab keuangan negara. Namun DPRD juga hadir sebagai lembaga dalam pranata demokrasi perwakilan memiliki kewenangan yang berkaitan dengan pemeriksaan pengelolaan dan tanggung jawab keuangan negara. Maka lembaga ini bertindak juga sebagai check and balances dalam akuntabilitas dimensi horizontal. Selain itu dengan posisi DPRD sebagai pelembagaan kedaulatan rakyat dalam demokrasi perwakilan, dan posisi BPK sebagai lembaga yang kewenangannya diberikan oleh undang-undang dasar dalam rangka melaksanakan kedaulatan rakyat, maka muncul pula akuntabilitas dalam dimensi vertikal. Hal tersebut berdampak pada terciptanya hubungan di antara kedua lembaga tersebut dalam rangka pelaksanan prinsip akuntabilitas sebagai perwujudan kedaulatan rakyat. Kondisi seperti ini tidak ditemukan sebelum adanya perubahan UUD 1945.

\section{a. Akuntabilitas horizontal}

Dalam pengelolaan keuangan daerah, DPRD terlibat berdasarkan fungsi yang dimilikinya, yakni fungsi penganggaran, fungsi legislasi, dan fungsi pengawasan. Fungsi pengawasan diterapkan dalam bentuk pengawasan terhadap pelaksanaan peraturan daerah dan turunannya, pelaksanaan peraturan perundang-undangan lain yang terkait dengan penyelenggaraan Pemerintahan Daerah, dan pelaksanaan tindak lanjut hasil pemeriksaan laporan keuangan oleh Badan Pemeriksa Keuangan. ${ }^{111}$ Fungsi pengawasan menjadi dominan dalam lingkup pemeriksaan pengelolaan dan tanggung jawab keuangan daerah. Sehingga DPRD juga menjalankan akuntabilitas terhadap pengelolaan keuangan daerah oleh pemerintah daerah.

Pelaksanaan desentralisasi fiskal berupa pengelolaan APBD oleh unsur Pemerintahan Daerah dan badan usaha yang dibiayai oleh APBD tentunya harus dipertanggungjawabkan. Mekanisme pertanggungjawaban (akuntabilitas) tersebut

111 Andi Pangerang Moenta dan Syafa'at Anugrah Pradana, Pokok-Pokok Hukum Pemerintahan Daerah, Depok: Rajawali Pers, 2018, hal. 68. 
dilaksanakan melalui pemeriksaan pengelolaan dan tanggung keuangan daerah oleh BPK, yang dalam hal ini dilakukan oleh BPK perwakilan yang terdapat di setiap provinsi. ${ }^{112}$ BPK perwakilan, ${ }^{113}$ melakukan pemeriksaan pengelolaan dan tanggung jawab keuangan negara kepada unsur pemerintahan daerah yaitu pemerintah daerah dan DPRD. Hal ini merupakan bagian dari check and balances antar lembaga negara sebagai bagian dari akuntabilitas. Tidak berhenti disitu, untuk tujuan akuntabilitas pula, BPK kemudian menyerahkan hasil pemeriksaannya kepada DPRD provinsi dan kabupaten/kota pada daerah provinsi terkait. Maka jelas terlihat hubungan kerja dalam kerangka akuntabilitas horizontal antar kedua lembaga.

Masih dalam kerangka dimensi akuntabilitas horizontal dalam rangka check and balances, perubahan UUD 1945 memberikan hal baru terkait hubungan antara BPK dan DPRD dalam konteks pemeriksaan pengelolaan dan tanggung jawab keuangan negara. Meskipun hubungan ini diatur dalam kerangka peraturan perudang-undangan di luar undang-undang dasar namun lahir setelah perubahan UUD 1945. Hal ini harus dilihat sebagai perwujudan kedaulatan rakyat dan sepanjang tidak bertentangan (inkonstitusional) menjadi bagian yang tidak terpisahkan dari undang-undang dasar. Menjadi lebih beralasan ketika hubungan ini menempatkan posisi penting DPRD sebagai wakil rakyat dalam pemeriksaan pengelolaan dan tanggung jawab keuangan daerah. Hal yang telah dimulai melalui kehadiran ketentuan Pasal 23E ayat (2) UUD NRI Tahun 1945.114 Hubungan tersebut yaitu Bentuk Tindak Lanjut Hasil Pemeriksaan dan keterlibatan DPRD dalam perencanaan tugas pemeriksaan.

\section{1) Bentuk Tindak Lanjut Hasil Pemeriksaan}

Ketentuan UUD NRI Tahun 1945 menyatakan bahwa selain diserahkan maka hasil pemeriksaan BPK harus ditindaklanjuti pula oleh DPRD sesuai dengan undangundang. ${ }^{115}$ Hal ini dinamakan sebagai Bentuk Tindak Lanjut Hasil Pemeriksaan.

\footnotetext{
112 Pasal 23G ayat (1) UUD NRI Tahun 1945 menyatakan "Badan Pemeriksa Keuangan berkedudukan di ibu kota negara, dan memiliki perwakilan di setiap provinsi."

113 BPK perwakilan merupakan pelaksana BPK di setiap provinsi yang mempunyai tugas memeriksa pegelolaan dan tanggung jawab keuangan daerah pada pemerintah provinsi terkait, kabupaten/kota di provinsi terkait, BUMD dan lembaga terkait di lingkungan entitas, termasuk melaksanakan pemeriksaan yang ditugaskan oleh pelaksana BPK lainnya secara struktural ke atas. Lihat Peraturan BPK RI No. 1 Tahun 2019 tentang Organisasi Dan Tata Kerja Pelaksana Badan Pemeriksa Keuangan.

114 Pasal 23E ayat (2) menyatakan "Hasil pemeriksaan keuangan negara diserahkan kepada Dewan Perwakilan Rakyat, Dewan Perwakilan Daerah, dan Dewan Perwakilan Rakyat Daerah, sesuai dengan kewenangannya."

115 Pasal 23E ayat (3) UUD NRI Tahun 1945.
} 
Bentuk Tindak Lanjut Hasil Pemeriksaan merupakan tindakan DPRD melakukan pembahasan hasil pemeriksaan, meminta penjelasan kepada BPK terkait hasil pemeriksaan, dan/atau dapat meminta BPK untuk melakukan pemeriksaan lanjutan. ${ }^{116}$ Lewat bentuk tindak lanjut ini, setelah penyerahan Laporan Hasil Pemeriksan, DPRD diharapkan melakukan follow up atas Laporan Hasil Pemeriksaan yang diserahkan oleh BPK, dalam hal ini BPK perwakilan pada setiap provinsi. Follow up yang diharapkan dapat berupa undangan bagi BPK perwakilan dalam rangka pembahasan secara terperinci terkait pemeriksaan yang telah dilaksanakan. Dalam pembahasan tersebut, DPRD juga dibenarkan untuk meminta penjelasan kepada BPK perwakilan terkait hal-hal yang dibutuhkan keterangannya. Dan, apabila dipandang perlu, DPRD dapat meminta BPK perwakilan untuk melakukan pemeriksaan lanjutan terkait satu atau beberapa bidang tertentu sebagai pengembangan dari pemeriksaan yang telah dilakukan sebelumnya.

2) Keterlibatan DPRD dalam Perencanaan Pemeriksaan

Proses pemeriksaan meliputi perencanaan, pelaksanaan, pelaporan dan pemantauan tindak lanjut hasil pemeriksaan. ${ }^{117}$ BPK bebas dan mandiri dalam memeriksa pengelolaan dan tanggung jawab keuangan negara. Kebebasan dan kemandirian ini dalam perencanaan, pelaksanaan, pelaporan, dan pemantauan tindak lanjut hasil pemeriksaan. Meskipun bebas dan mandiri, BPK dapat melibatkan institusi lain dalam perencanaan pemeriksaan. Institusi tersebut yaitu lembaga perwakilan, dalam hal ini, DPR, DPD dan DPRD. Hal ini merupakan ketentuan peraturan perundang-undangan yang mengatr bahwa dalam merencanakan tugas pemeriksaan, BPK memerhatikan permintaan, saran, dan pendapat lembaga perwakilan. ${ }^{118}$ Dalam konteks ini adalah BPK Perwakilan yang terdapat di setiap provinsi dengan DPRD provinsi, kabupaten dan kota pada provinsi tersebut.

b. Akuntabilitas vertikal

DPRD merupakan pranata kedaulatan rakyat (demokrasi) perwakilan bagi rakyat di daerah. Sehingga penyerahan hasil pemeriksaan oleh BPK perwakilan kepada DPRD merupakan bagian dari akuntabilitas kepada rakyat yang diwakili oleh

116 Pasal 21 UU No. 15 Tahun 2004 tentang Pemeriksaan Pengelolaan dan Tanggung Jawab Keuangan Negara. 117 Lampiran I Peraturan BPK No. 1 Tahun 2017 tentang Standar Pemeriksaan Keuangan Negara.

118 Pasal 7 ayat (1) UU No. 15 Tahun 2004 tentang Pemeriksaan Pengelolaan dan Tanggung Jawab Keuangan Negara 
lembaga perwakilan. Hal ini merupakan check and balances dalam dimensi horizontal sekaligus pelaksanaan akuntabilitas dalam dimensi vertikal. Ketentuan Pasal 1 ayat (2) UUD NRI Tahun 1945 yakni "Kedaulatan berada di tangan rakyat dan dilaksanakan menurut Undang-Undang Dasar" menunjukkan bahwa setiap lembaga negara yang diatur kewenangannya dalam undang-undang dasar melaksanakan kedaulatan rakyat. Maka, BPK yang diberikan kewenangan untuk memeriksa pengelolaan dan tanggung jawab tentang keuangan negara merupakan perwujudan kedaulatan rakyat. Sehingga pemeriksaan pengelolaan dan tanggung jawab keuangan daerah kepada DPRD selaku unsur pemerintah daerah menjadi pelaksanaan prinsip akuntabilitas dalam dimensi vertikal.

\section{KESIMPULAN}

Perubahan UUD 1945 menjadi UUD NRI Tahun 1945 mereposisi kedaulatan rakyat. Sebelum perubahan, kedaulatan rakyat berada di tangan rakyat namun dilaksanakan sepenuhnya oleh MPR. Sementara setelah perubahan kedaulatan tetap berada di tangan rakyat namun kini dilaksanakan menurut undang-undang dasar. Alhasil, seluruh ketentuan dalam undang-undang dasar mencerminkan penjelmaan kedaulatan rakyat. Dalam pelaksanaannya, kedaulatan rakyat diwujudkan melalui salah satu prinsipnya yakni akuntabilitas. Prinsip akuntabilitas merupakan perwujudan kedaulatan rakyat sebagai bentuk pertanggungjawaban kepada rakyat selaku pemberi mandat. Prinsip ini pula yang mendasari hubungan antara DPRD dengan BPK yang secara mandiri memiliki kewenangan dalam rangka pelaksanaan akuntabilitas. DPRD selaku lembaga pengawasan pengelolaan keuangan daerah dan BPK sebagai pemeriksa pengelolaan dan tanggung jawab keuangan daerah. Pelaksanaan kewenangan tersebut ternyata menimbulkan hubungan antar kedua lembaga. Hubungan antar kedua lembaga merupakan, pertama, pelaksanaan akuntabilitas dalam rangka check and balances antar lembaga negara sebagai akuntabilitas dalam dimensi horizontal. Hubungan tersebut secara garis besar meliputi, pemeriksaan oleh BPK terhadap pengelolaan dan tanggung jawab keuangan daerah yang dilaksanakan oleh DPRD sebagai salah satu unsur pemerintahan daerah; penyerahan laporan hasil pemeriksaan pengelolaan dan tanggung jawab keuangan daerah oleh pemerintahan daerah kepada DPRD; Bentuk Tindak Lanjut Hasil 
Pemeriksaan berupa tindakan DPRD melakukan pembahasan hasil pemeriksaan kepada BPK, meminta penjelasan kepada BPK terkait hasil pemeriksaan, dan/atau dapat meminta BPK untuk melakukan pemeriksaan lanjutan; dan keterlibatan DPRD dalam perencanaan pemeriksaan. Kedua, akuntabilitas dalam dimensi vertikal berupa pertanggungajawaban kepada rakyat.

\section{DAFTAR PUSTAKA}

\section{Buku-buku}

Atmadja, Arifin P. Soeria. Keuangan Publik dalam Perspektif Hukum, Jakarta: Rajawali Pers, 2017.

Asshiddiqie, Jimly. Pokok-Pokok Hukum Tata Negara Indonesia, Jakarta: BIP, 2008.

Asshiddiqie, Jimly. Konstitusi dan Konstitusionalisme Indonesia, Jakarta: Sinar Grafika, 2010.

Bo, Eduardus Marius. Teori Negara Hukum dan Kedaulatan Rakyat, Malang: Setara Press, 2019.

Fahmi, Khairul. Pemilihan Umum dan Kedaulatan Rakyat, Jakarta: Rajawali Pers, 2012.

Gaffar, Janedri M., Demokrasi dan Pemilu di Indonesia, Jakarta: Konstitusi Pers, 2013.

Halim, Abdul dan Muhammad Iqbal (ed.), Pengelolaan Keuangan Daerah, Yogyakarta: UPP STIM YKPN, 2019.

Hatta, Mohammad. Demokrasi Kita, Bandung: Sega Arsy, 2018.

Hart, H.L.A., Konsep Hukum (The Concept of Law), Bandung: Nusamedia, 2016.

Isra, Saldi. Lembaga Negara (Konsep, Sejarah, Wewenang, dan Dinamika Konstitusional), Jakarta: Rajawali Pers, 2020.

Jurdi, Fajlurrahman. Hukum Tata Negara Indonesia, Jakarta: Prenadamedia Group, 2019.

Karianga, Hendra. Politik Hukum dalam Pengelolaan Keuangan Daerah, Jakarta: Prenadamedia Group, 2015.

Kelsen, Hans. Teori Umum Tentang Hukum Dan Negara, Bandung: Nusamedia, 2016.

Marzuki, Peter Mahmud. Penelitian Hukum, Jakarta: Kencana Media Group, 2014.

Mill, Jhon Stuart. On Liberty, Ontario: Batoche Books Limited, 2001.

Moenta, Andi Pangerang dan Syafa'at Anugrah Pradana, Pokok-Pokok Hukum Pemerintahan Daerah, Depok: Rajawali Pers, 2018.

Molino, Leonardo. Equality, Freedom, and Democracy (Europe After the Great Recession), New York: Oxford Unversity Press, 2020. 
OECD, DAC Guidelines and Reference Series: Accountability and Democratic Governance (Orientations and Principles for Development), Paris: OECD Publishing.

Rawls, Jhon. Teori Keadilan (Prinsip-Prinsip Filsafat Politik untuk Mewujudkan Kesejahteraan Sosial Dalam Negara), Yogyakarta: Pustaka Pelajar, 2011.

Russel, Bertrand. Sejarah Filsafat Barat (Kaitannya dengan Kondisi Sosio-Politik Zaman Kuno Hingga Sekarang, Yogyakarta: Pustaka Pelajar 2016.

Strong, C.F. Konstitusi-Konstitusi Politik Modern, Bandung: Nusamedia, 2008.

Suseno, Franz Magnis. Etika Politik (Prinsip Moral Dasar Kenegaraan Modern), Jakarta: Gramedia Pustaka Utama.

Tutik, Titik Triwulan. Konstruksi Hukum Tata Negara Indonesia Pasca Amandemen UUD 1945, Kencana, Jakarta, 2010.

\section{Artikel atau Jurnal}

Abdul, Kadir Jaelani dan Udiyo Basuki. "Illegal Unreported And Unregulated (IUU) Fishing: Upaya Mencegah Dan Memberantas Illegal Fishing Dalam Membangun Poros Maritim Indonesia." Supremasi Hukum, Juni 2014: Volume 3, Nomor 1.

Abdul Gafoor, K. "Validation of Scale of Commitment to Democratic Values among Secondary Students", Guru Journal of Behavioral and Social Sciences, JanuariMaret 2015: Volume 3, Issue 1.

Aji, Alan Bayu, "Implikasi Politik Hukum Pengaturan Pertanggungjawaban Kinerja Kepala Daerah Pasca Reformasi”, Lex Rennaisance, Juli 2017: Volume 2, Nomor 2.

Anderson, Elizabeth S. “What is the Point of Equality?”, Ethics, Januari 1999: Volume 109, Number 2.

Andrews, J.S., "Liberal Equality and the Justification of Multicultural, Civic Education." Canadian Journal of Law \& Jurisprudence, Juni 1994: Volume 7, Number 1.

Andryan, M. Solly Lubis, Suhaidi, Faisal Akbar Nasution. "Penguatan Fungsi Legislasi Dewan Perwakilan Daerah Dalam Sistem Ketatanegaraan Republik Indonesia (Analisis Putusan Mahkamah Konstitusi No.92/Ppu-X/2012)”, USU Law Journal, Agustus 2015: Volume 3, Nomor 2.

Azhimy, Desyari. Wiyaliyanti, Untung Dwi Hananto dan Henny Juliani, "Hubungan Kerja Badan Pemeriksa Keuangan Pusat Dengan Badan Pemeriksa Keuangan Perwakilan Provinsi Jawa Tengah Dalam Memeriksa Pengelolaan Dan Pertanggungjawaban Keuangan Di Daerah", Diponegoro Law Journal, Juni 2015: Volume 5, Nomor 3.

Fahmi, Khairul. "Prinsip Kedaulatan Rakyat Dalam Penentuan Sistem Pemilihan Umum Anggota Legislatif”, Jurnal Konstitusi Mahkamah Konstitusi, Juni 2010: Volume 
Nuh, Muhammad Syarif. "Hakikat Pertanggungjawaban Pemerintah Daerah Dalam Penyelenggaraan Pemerintahan”, Jurnal MMH, Januari 2012: Volume 41, Nomor 1.

Palguna, I Dewa Gede. "Perspektif Teoritik Eksistensi Mahkamah Konstitusi (Pasca Perubahan Uud 1945)", Jurnal Konstitusi Mahkamah Konstitusi, November 2005: Volume 2, Number 3.

Post, Robert. "Democracy and Equality", The ANNALS of the American Academy of Political and Social Science, January 2006: Volume 603, Number 1.

Prama Jasa, Gilang dan Ratna Herawati. "Dinamika Relasi Antara Badan Pemeriksa Keuangan Dan Dewan Perwakilan Rakyat Dalam Sistem Audit Keuangan Negara", Jurnal Law Reform, September 2017: Volume 13, Nomor 2.

Ridlwan, Zulkarnain. "Cita Demokrasi Indonesia dalam Politik Hukum Pengawasan Dewan Perwakilan Rakyat terhadap Pemerintah", Jurnal Konstitusi Fakultas Hukum Universitas Lampung, Juni 2015: Volume 12, Nomor 2.

Rikardo, Ofis. "Penerapan Kedaulatan Rakyat Di Dalam Pemilihan Umum Di Indonesia Berdasarkan Undang-Undang Dasar Negara Republik Indonesia Tahun 1945”, Jurnal Hukum Sasana, Juni 2020: Volume 6, Nomor 1.

\section{Data Internet}

Castiglione, Dario. 22 Oktober 2012, "Accountability", Encyclopedia Britannica, lihat dalam https://www.britannica.com/topic/accountability, diakses pada tanggal 28 Agustus 2021.

Equality and Human Rights Comission, 02 Agustus 2018, "Understanding Equality", lihat dalam https://www.equalityhumanrights.com/en/secondary-educationresources/useful-information/understanding-equality, diakses pada tanggal 22 Agustus 2021

Institute For Goverment, 15 Oktober 2018, “Accountability In Modern Government Recommendations For Change", https://www.instituteforgovernment.org.uk/publications/accountabilitymodern-government-recommendations, diakses pada tanggal 20 Agustus 2021.

Mahkamah Konstitusi Republik Indonesia, 11 Agustus 2015, “Hak Dan Kewajiban Warga Negara Indonesia Dengan UUD 45", liat dalam https://www.mkri.id/index.php?page=web.Berita\&id=11732, diakses pada tanggal 20 Agustus 2021.

Shidarta, 24 Oktober 2014, "Desiderata Hukum", lihat dalam https://businesslaw.binus.ac.id/2014/10/24/desiderata-hukum/, diakses pada tanggal 29 Agustus 2021.

USAID, 13 Agustus 2021, "Promoting Accountability and Transparency", lihat dalam https://www.usaid.gov/what-we-do/democracy-human-rights-andgovernance/promoting-accountability-transparency, diakses pada tanggal 17 Agustus 


\section{Peraturan Perundang-undangan}

Undang-Undang Dasar 1945.

Undang-Undang Dasar Negara Republik Indonesia Tahun 1945.

Undang-Undang Nomor 17 Tahun 2003 tentang Keuangan Negara (Lembaran Negara Republik Indonesia Tahun 2003 Nomor 47, Tambahan Lembaran Negara Republik Indonesia Nomor 4286).

Undang-Undang Nomor 15 Tahun 2006 tentang Badan Pemeriksa Keuangan (Lembaran Negara Republik Indonesia Tahun 2006 Nomor 85, Tambahan Lembaran Negara Republik Indonesia Nomor 4654. 